\title{
Originals
}

\section{Trans-racial studies implicate HLA-DQ as a component of genetic susceptibility to Type 1 (insulin-dependent) diabetes}

\author{
J. Fletcher, C. Mijovic, O. Odugbesan, D.Jenkins, A. R. Bradwell and A. H. Barnett \\ Departments of Medicine and Immunology, University of Birmingham, and East Birmingham Hospital, UK
}

\begin{abstract}
Summary. Type 1 (insulin-dependent) diabetic patients and control subjects of Afro-Caribbean Negroid racial origin were investigated by serological HLA-DR-typing and restriction fragment length polymorphism analysis using DNA probes corresponding to the $\mathrm{DQ} \alpha, \mathrm{DQ} \beta$ and $\mathrm{DR} \beta$ chain genes. Combined analysis indicated that four DR antigens are positively associated with the condition in Negroid subjects - DR3, 4, 7 and w9. DR3 and 4 are also associated in Caucasians, but the relative risk for DR3 is lower in Negroid subjects. The DR7 association is specific for the Negroid race, and DRw9 is only weakly associated in Caucasoid subjects. Restriction fragment length polymorphism analysis demonstrated a $D Q \beta$ restriction pattern in Negroid subjects which is absent from Caucasoid subjects. This pattern was associated with DRw9 and a
\end{abstract}

subset of DR7, and was markedly increased in frequency in diabetic patients compared with control subjects $(48.7 \%$ vs $10.4 \%$, respectively; $p<10^{-4}$ ). In the absence of this pattern, DR7 showed no positive association. DR3 in Negroid subjects was associated with two distinct DQ $\alpha-D Q \beta$ patterns, only one of which was positively associated with diabetes. $A D Q \beta$ pattern, in linkage disequilibrium with different DR antigens in different races, conferred a consistent protective effect against the development of Type 1 diabetes. Trans-racial genetic analysis thus supports a primary role for DQ in susceptibility to Type 1 diabetes.

Key words: Type 1 (insulin-dependent) diabetes, HLA-DQ, racial studies.
The association of Type 1 (insulin dependent) diabetes with certain DR antigens indicates that a major part of its genetic susceptibility is located close to, or within, the HLA-D (class II HLA) region. Recent studies have pointed to the DQ subregion as a potential determinant of disease predisposition [1-9]. Identification of the primary susceptibility locus (or loci) is complicated, however, by linkage disequilibrium. This refers to the strong tendency of HLA alleles to co-associate non-randomly to form specific haplotype combinations. HLA linkage relationships vary in different races, and, thus, comparison of HLA-disease associations in distinct ethnic populations may define the primary site of genetic predisposition [10].

The relative risk for Type 1 diabetes conferred by certain DR antigens shows racial variation. DRw9, for example, is increased in frequency in diabetic patients of Japanese origin [11], but the relative risk for this antigen in Caucasoid subjects is close to one [12]. This variation suggests that the serologically-defined DR antigens do not correspond directly to disease susceptibility alleles, but it may help to identify these factors. If an antigen shows a race-specific association with Type 1 diabetes, the question arises "what allele is found on haplotypes bearing this antigen in the race(s) in which it is diabetes-associated, which is absent from haplotypes bearing the same antigen in other populations?". The genetic locus encoding this allele will be a candidate for a primary determinant of genetic susceptibility to Type 1 diabetes.

In an attempt to define race-specific disease associations, we have serologically DR-typed Negroid patients with Type 1 diabetes and racially-matched control subjects. Associations thus defined were further investigated by restriction fragment length polymorphism (RFLP) analysis using DNA probes corresponding to the $\mathrm{DQ} \alpha, \mathrm{DQ} \beta$ and $\mathrm{DR} \beta$ chain genes.

\section{Subjects and methods}

\section{Subjects}

Type 1 diabetic patients and control subjects were UK residents of Afro-Caribbean (predominantly Jamaican) Negroid racial origin, with no known Caucasoid ancestry. Control subjects were healthy un- 
Table 1. Clinical characteristics of diabetic patients

Non-obese

Acute onset of symptoms

Under 30 years of age at diagnosis

Frank clinical ketoacidosis or heavy non-fasting ketonuria $(+++$ on stick testing) at presentation

Absolute requirement for insulin from diagnosis

Table 2. HLA-DR antigen frequencies in Negroid Type 1 diabetic patients and control subjects

\begin{tabular}{ccccl}
\hline $\begin{array}{l}\text { HLA-DR } \\
\text { antigen }\end{array}$ & Patients & \multicolumn{2}{c}{ Control subjects } & \\
\cline { 3 - 5 } & $(n=39)$ & $(n=80)^{\mathrm{a}}$ & $\mathrm{RR}$ & $p_{\mathrm{c}}$ \\
\hline 1 & $3(7.7)$ & $11(13.8)$ & 0.58 & $\mathrm{NS}$ \\
2 & $2(5.1)$ & $24(30.0)$ & 0.15 & $<0.025$ \\
3 & $15(38.5)$ & $21(26.3)$ & 1.8 & $\mathrm{NS}$ \\
4 & $15(38.5)$ & $2(2.5)$ & 20 & $<10^{-4}$ \\
5 & $3(7.7)$ & $34(42.5)$ & 0.13 & $<0.002$ \\
w 6 & $8(20.5)$ & $22(34.4)$ & 0.51 & NS \\
7 & $11(28.2)$ & $9(11.3)$ & 3.0 & NS \\
w 8 & $4(10.3)$ & $6(9.4)$ & 1.1 & NS \\
w 9 & $9(23.1)$ & $3(4.7)$ & 5.5 & NS \\
w10 & $0(0)$ & $1(1.6)$ & 0.54 & NS \\
\hline
\end{tabular}

This table shows the numbers (percentages) of patients and control subjects with each DR antigen. $n=$ total number of subjects in each group. ${ }^{a}$ for DRw6, w8, w9 and w10, $n=39$ for the patient group, and $n=64$ for the control subjects. $\mathrm{RR}=$ relative risk; $p_{\mathrm{c}}=$ corrected significance level; NS = non-significant

related individuals with no personal or family history of diabetes. All patients fulfilled the classic clinical criteria for insulin-dependence (see Table 1).

\section{Methods}

Patients and control subjects were studied by: (1) serological HLADR-typing (39 patients and 80 control subjects). (2) DQ $\alpha, D Q \beta$ and DR $\beta$ RFLP analysis (39 patients and 77 control subjects).

DR-typing was by a standard microlymphocytotoxicity method using commercially prepared typing trays (Biotest, Birmingham, UK). These trays are in routine clinical use in the United Kingdom for tissue typing prior to bone marrow transplantation. DR1-5\& 7 were determined in all subjects. DRw6, w8, w9 and w10 were defined in all 39 patients and in 64 control subjects. The typing trays included the following numbers of specific antisera: DR1 - four; DR2 - five; DR3 - five; DR4 - five; DR5 - five; DR7 - five; DRw8 - two; DRw10 two. For DRw6, five antisera were included, two of which were crossreactive with DR3, and three of which cross-reacted with the other DQw1-related antigens DR1, 2 and w10. For DRw9, three antisera were employed, two of which cross-reacted with DR4 and one of which cross-reacted with DR1 and w10. DR antigen assignments were confirmed by DR $\beta$ probing (see below "Restriction fragment length polymorphism analysis").

For the RFLP studies, DNA was isolated from peripheral blood. Ten $\mu g$ DNA were digested with restriction enzymes BamHI, Eco RI or TaqI under conditions recommended by the manufacturer (BRL, Glasgow, UK). Digested DNA was separated by electrophoresis in $0.7 \%$ agarose at $50 \mathrm{~V}, 25 \mathrm{~mA}$ for $18 \mathrm{~h}$ (TaqI and BamHI digests) or $22 \mathrm{~h}$ (EcoRI digests) and Southern blotted onto nylon filters (Hybond-N, Amersham Int., Amersham, UK) [13]. Three cDNA probes were used: (1) the HindIII/PstI insert of pII $\beta 1$ (full-length DQ $\beta$ chain); (2) the ApaI fragment of pII $\alpha 5$ (full-length DQ $\alpha$ chain); (3) the 500 base pair PstI fragment of pII $\beta 4$ (corresponding to the second domain, transmembrane, cytoplasmic and 3 -untranslated portions of DR $\beta$ chain). The restriction enzymes used were BamHI (DQ $\beta$ ), EcoRI $(D Q \beta)$ and TaqI (DQ $\beta, D Q \alpha$ and DR $\beta$ ). Probes were labelled to a specific activity of $10^{9} \mathrm{cpm} / \mu \mathrm{g}$ DNA by the oligonucleotide primer method. Prehybridisation and hybridisation were performed at $65^{\circ} \mathrm{C}$ in $6 \times$ standard sodium citrate solution (SSC; $1 \times \mathrm{SSC}=0.15 \mathrm{~mol} / 1$ $\mathrm{NaCl}, 0.015 \mathrm{~mol} / \mathrm{l} \mathrm{Na}$ citrate), $5 \times$ Denhardt's solution, $0.5 \%$ sodium dodecyl sulphate (SDS) with $250 \mu \mathrm{g} / \mathrm{ml}$ denatured salmon sperm DNA. Ten percent dextran sulphate was used in the hybridisation solution. After hybridisation, filters were rinsed in $2 \times \mathrm{SSC}, 0.1 \% \mathrm{SDS}$, twice, at room temperature, then washed in the same solution at $65^{\circ} \mathrm{C}$ for $30 \mathrm{~min}$, in $0.5 \times \mathrm{SSC}, 0.1 \% \mathrm{SDS}$ at $65^{\circ} \mathrm{C}$ for $60 \mathrm{~min}$, followed by four 15 -min washes in $0.1 \times \mathrm{SSC}, 0.1 \% \mathrm{SDS}$ at $65^{\circ} \mathrm{C}$. After air drying, autoradiography was performed for 3 days at $-70^{\circ} \mathrm{C}$.

\section{Statistical analysis}

Statistical analysis of associations of DR antigens and DQ RFLPs with Type 1 diabetes was by the $\mathrm{X}^{2}$ test, or Fisher's exact test, as appropriate. Corrected significance levels $\left(\mathrm{p}_{\mathrm{c}}\right)$ werer calculated by multiplying the " $p$ value" by the number of statistical comparisons performed at each locus. Relative risk (RR) estimates are given with $95 \%$ confidence intervals in brackets. RR estimates, $95 \%$ confidence intervals for RR, combined RR risk estimates, and significance levels for RR estimates were determined by the method of Woolf with the Haldane modification for small numbers [14-16].

\section{Results}

\section{$H L A-D R$ serological analysis}

The DR antigen frequencies in Negroid diabetic patients and control subjects are shown in Table 2. DR4 was markedly increased in frequency in the patients, but was rare in the control population ( $38.5 \%$ vs $2.5 \%$; $\left.\mathrm{RR}=20(5.4-74) ; p_{\mathrm{c}}<10^{-4}\right)$. DR3 was non-significantly increased in frequency in patients compared with control subjects $(38.5 \%$ vs $26.3 \% ; R R=1.8(0.81-4.0))$, as were DR7 $(28.2 \%$ vs $11.3 \% ; R R=3.0(1.2-7.7))$ and DRw9 $(23.1 \%$ vs $4.7 \%$; $R R=5.5(1.6-19))$.

$\mathrm{DR} 3 / 4$ heterozygosity was non-significantly increased in frequency in patients compared with control subjects $(10.3 \%$ vs $0 \%)$. DR3, DR4, or both antigens, were found in $66.7 \%$ patients and $28.8 \%$ control subjects $\left(R R=4.8(2.2-11) ; p_{c}<0.001\right)$. DR3, DR4, DR7 or DRw9 (or any two of these antigens) were found in $36 / 39(92.3 \%)$ patients and $28 / 64(43.8 \%)$ control subjects $\left(R R=13(4.3-42) ; p_{\mathrm{c}}<10^{-5}\right)$.

DR2 was reduced in frequency in patients vs control subjects $\quad(5.1 \% \quad$ vs $\quad 30.0 \% ; \quad \mathrm{RR}=0.15 \quad(0.04-0.55)$; $\left.p_{\mathrm{c}}<0.025\right)$, as was DR5 (7.7\% vs $42.5 \% ; \mathrm{RR}=0.13$ $\left.(0.04-0.40) ; p_{\mathrm{c}}<0.002\right)$.

\section{Combined analysis}

In view of the increased frequency (non-significant) of DR3, DR7 and DRw9 in this study, combined analysis of these data with those of all previously published 
studies of DR antigens in Negroid subjects with Type 1 diabetes [17-23] was performed, to determine whether there were significant associations with these markers (only four published studies tested for DRw9 [20-23]).

The combined RR estimate for DR3 was 1.94 $(1.48-2.53)$; this was significantly different from one $\left(\mathrm{X}^{2}(1 \mathrm{df})=23.5 ; p_{\mathrm{c}}<0.001\right)$. Further analysis indicated significant variation (heterogeneity) among $R R$ estimates for DR3 $\left(\mathrm{X}^{2}(7 \mathrm{df})=18.8 ; p<0.01\right)$. Removal of a data set derived from a study in American Negroid patients [17] (which gave a relatively high RR estimate for DR3 (5.9)) from the analysis gave non-significant heterogeneity $(p>0.05)$, and a combined RR value for DR3 of $1.71(1.29-2.27)$. This was significantly different from one $\left(p_{\mathrm{c}}<0.002\right)$.

The combined RR estimate for DR7 was 1.71 $(1.25-2.35)$. This was significantly different from one $\left(\mathrm{X}^{2}(1 \mathrm{df})=11.1 ; p_{\mathrm{c}}<0.01\right)$. The RR estimates showed significant variation $\left(\mathrm{X}^{2}(7 \mathrm{df})=17.3 ; p<0.025\right)$. Removal of a data set derived from a study of Ethiopian Negroid subjects [23] (in which DR7 was reduced in diabetic patients) from the analysis gave non-significant heterogeneity $(p>0.2)$, and a combined RR value for DR7 of $1.95(1.41-2.70)$. This was significantly different from one $\left(p_{c}<0.001\right)$.

The combined RR estimate for DRw9 was 4.53 $(2.23-9.19)\left(\mathrm{X}^{2}(1 \mathrm{df})=17.5 ; p_{\mathrm{c}}<0.001\right)$. The RR estimates were not significantly heterogeneous $\left(\mathrm{X}^{2}\right.$ $(4 \mathrm{df})=2.2 ; p>0.5)$.

\section{Restriction fragment length polymorphism analysis}

DQ $\beta$ RFLPs were the same as those previously described in Caucasoid subjects [10, 24, 25], apart from a novel pattern, found only in Negroid subjects, designated DQ $\beta$ VIIc. Table 3 shows the restriction fragments for each DQ $\beta$ RFLP. Correlations between the DQ $\beta$ DNA fragment patterns obtained with the three restriction enzymes (BamHI, TaqI and EcoRI) were based on (1) published studies which analysed DQ $\beta$ polymorphism with these three restriction enzymes in homozygous typing cells [25] and in pedigrees [3], and (2) the empirical observation that the correlations defined in these studies were also seen in Afro-Caribbean patients and control subjects. DQ $\beta$ VIIc has not been previously recognised, but the other RFLPs listed in Table 3 are known to be DQB-specific [3].

BamHI fragments were the same for DQBVIIb and DQBVIIc. The distinction was made by a TaqI $4 \mathrm{~kb}$ fragment in DQ $\beta$ VIIc, instead of the $8 \mathrm{~kb}$ fragment characteristic of DQ $\beta$ VIIb (see Fig. 1). The DQ-specificity of DQßVIIc was supported by the observation that the $4 \mathrm{~kb}$ fragment gave a strong hybridisation signal, and that it was not visible on filters rehybridised with DR $\beta$ probe. EcoRI fragments also varied, with an $18 \mathrm{~kb}$ fragment in DQ $\beta$ VIIb and a $13 \mathrm{~kb}$ fragment in DQBVIIc.
Table 3. DNA restriction fragments characteristic of each DQ $\beta$ restriction fragment length polymorphism

\begin{tabular}{lccc}
\hline DQ $\beta$ & \multicolumn{2}{l}{ DNA restriction fragments $(\mathrm{kb})$} \\
\cline { 2 - 4 } Pattern & BamHI & TaqI & EcoRI \\
\hline I & $6.2+3.2$ & 5.5 & 13 \\
III & $7.0+4.0$ & $2.5+1.5$ & 13 \\
IV & 12 & 1.8 & $18+5.0$ \\
V & $7.0+3.7$ & 4.6 & $13+5.0$ \\
VIa & $7.0+3.0$ & 3.2 & $9+2.2$ \\
VIb & 7.0 & 5.5 & $9+2.2$ \\
VIIb & $4.0+3.2$ & $8.0+2.5+1.5$ & $18+7.5$ \\
VIIc & $4.0+3.2$ & $4.0+2.5+1.5$ & $13+7.5$ \\
\hline
\end{tabular}

$\mathrm{kb}=$ DNA fragment size in kilobases

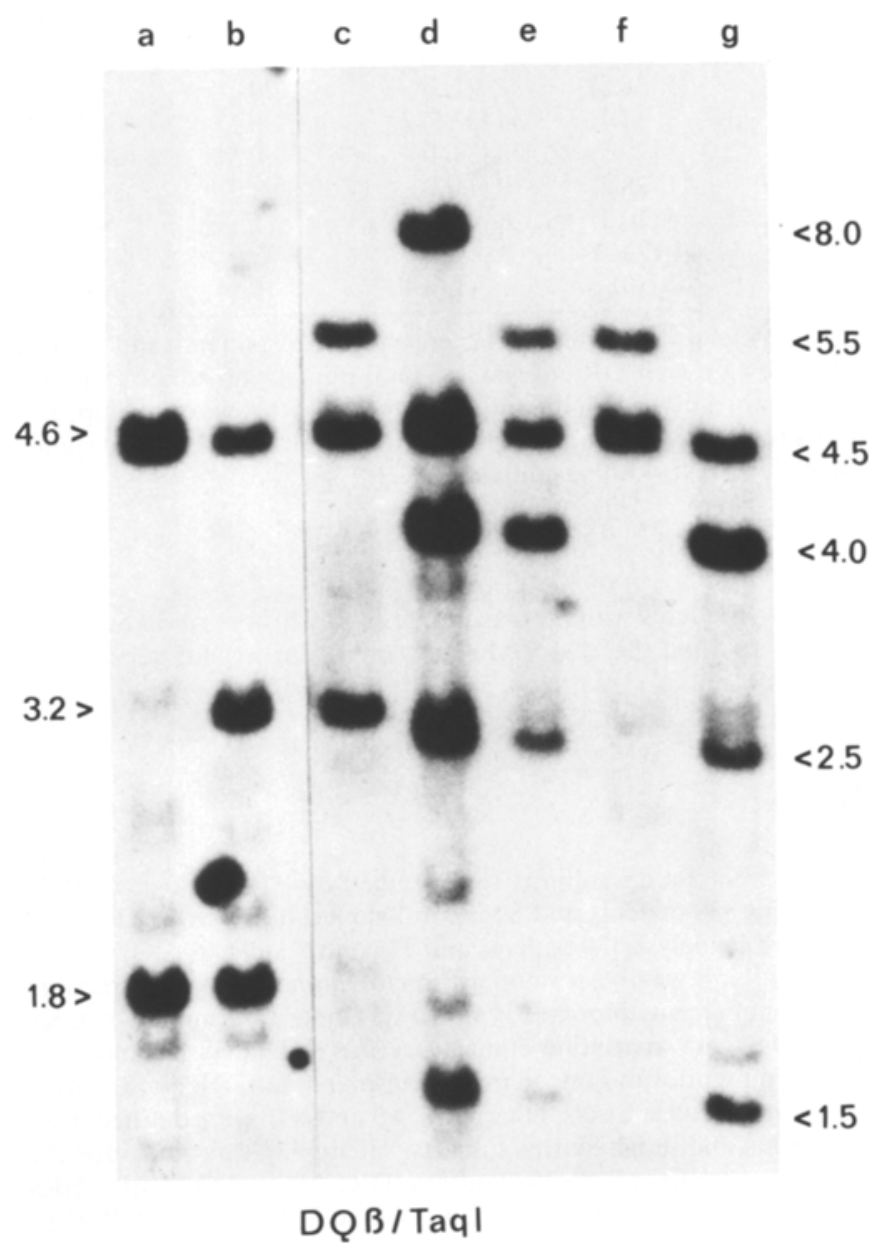

Fig. 1. DNA restriction fragment patterns obtained with $D Q \beta$ probe and restriction enzyme TaqI. Tracks $\mathrm{d}$, e, and g show the $4.0 \mathrm{~kb}$ fragment characteristic of DQ $\beta$ VIIc. Track d also shows the $8.0 \mathrm{~kb}$ fragment characteristic of $D Q \beta V I I b$

The frequencies of the DQ $\beta$ RFLPs are shown in Table 4. DQBVIIc was markedly increased in frequency in patients compared with control subjects $(48.7 \%$ vs $\left.10.4 \% ; R R=7.8(3.1-20) ; p_{c}<10^{-4}\right)$. DQ $\beta$ VIIb showed no association. DQ $\beta$ III was also increased in patients vs control subjects $(35.9 \%$ vs $13.0 \%$; $R R=3.7$ (1.5-9.1); $\left.p_{\mathrm{c}}<0.04\right)$. DQ $\beta \mathrm{IV}$ was non-significantly increased in 
Table 4. DQ $\beta$ RFLP frequencies in Negroid Type 1 diabetic patients and control subjects

\begin{tabular}{lrlll}
\hline DQR & Patients & \multicolumn{2}{l}{ Control subjects } & \\
\cline { 3 - 5 } Pattern & $(n=39)$ & $(n=77)$ & RR & $p_{\mathrm{c}}$ \\
\hline I & $6(15.4)$ & $25(32.5)$ & 0.40 & NS \\
III & $14(35.9)$ & $10(13.0)$ & 3.7 & $<0.04$ \\
IV & $15(38.5)$ & $17(22.1)$ & 2.2 & NS \\
V & $6(15.4)$ & $28(36.4)$ & 0.34 & NS \\
VIa & $4(10.3)$ & $33(42.9)$ & 0.17 & $<0.005$ \\
VIb & $3(7.7)$ & $10(13.0)$ & 0.62 & NS \\
VIIb & $5(12.8)$ & $12(15.6)$ & 0.84 & NS \\
VIIc & $19(48.7)$ & $8(10.4)$ & 7.8 & $<10^{-4}$ \\
\hline
\end{tabular}

This table shows the numbers (percentages) of patients and control subjects with each DQ $\beta$ RFLP. $n=$ total number of subjects in each group. Six patients and eleven control subjects are presumptive homozygotes.

$\mathrm{RR}=$ relative risk $; p_{\mathrm{c}}=$ corrected significance level $; \mathrm{NS}=$ non-significant

Table 5. DNA restriction fragments characteristic of each DR $\beta$ RFLP

\begin{tabular}{lr}
\hline DR $\beta$ pattern & TaqI/DR $\beta$ fragments \\
\hline I & $6.0+4.5$ \\
II & $12+2.0+1.5$ \\
III & $12+7.0+4.0$ \\
IV & $16+6.0+5.5+2.5$ \\
V & $10+6.5+4.0$ \\
VI & $10+7.0+4.0$ \\
VII & $16+6.0 / 7.0+4.0+2.5$ \\
\hline
\end{tabular}

The table shows the size (in kilobases) of the DNA fragments characteristic of each DR $\beta$ RFLP. DR $\beta$ VII may include either a 6.0 or $7.0 \mathrm{~kb}$ fragment

patients (38.5\% vs $22.1 \%$ of control subjects). DQ $\beta$ VIa was markedly reduced in patients vs control subjects $\left(10.3 \%\right.$ vs $\left.42.9 \% ; \mathrm{RR}=0.17(0.06-0.49) ; p_{\mathrm{c}}<0.005\right)$.

RFLPs defined with DR $\beta$ and DQ $\alpha$ probes were the same as those seen in Caucasoid subjects [10, 24, 25]. DR $\beta$ RFLPs defined with TaqI were classified into seven patterns which are listed in Table 5. These patterns correlate closely with serologically-defined DRtypes [10, 24, 25]. DQ $\alpha$ probing with TaqI defined fragments of size $2.6,4.6,5.5,6.2$ and $6.8 \mathrm{~kb}$ which are known to represent alleles of the DQ $\alpha$ gene [26].

\section{Relationships between $D R$ antigens and $D Q$ and DR RFLPS}

There were close associations (due to linkage disequilibrium) between DR antigens and $D Q \alpha$ and $D Q \beta$ RFLPs. Table 6 shows the DR antigen-DQ $\beta$ RFLP relationships (defined in control subjects), and Table 7 shows, for selected DR antigens, the most commonly associated $\mathrm{DR} \beta / \mathrm{DQ} \beta / \mathrm{DQ} \alpha$ RFLP combinations. Many of the associations were similar to those previously found in Caucasoid subjects $[10,24,25]$, but the following differences were seen in Negroid subjects: (1) the novel RFLP, DQBVIIc, was found in association
Table 6. Associations between DR antigens and DQ $\beta$ RFLPs

\begin{tabular}{|c|c|c|c|c|c|}
\hline Association & ++ & +- & -+ & -- & $p$ \\
\hline DR1:DQß1 & 9 & 0 & 11 & 44 & $<10^{-4}$ \\
\hline DR2:DQBVIa & 18 & 4 & 13 & 29 & $<10^{-4}$ \\
\hline DR3:DQß̈III & 8 & 11 & 1 & 44 & 0.001 \\
\hline DR3:DQBIV & 11 & 8 & 3 & 42 & $<10^{-4}$ \\
\hline DR4:DQBIV & 1 & 0 & 13 & 50 & NS \\
\hline DR5:DQBV & 14 & 8 & 9 & 33 & $<0.001$ \\
\hline DR5:DQBVIa & 12 & 10 & 19 & 23 & NS \\
\hline DRw6:DQ $\beta$ VIa $+b$ & 14 & 4 & 19 & 24 & $<0.02$ \\
\hline 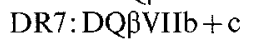 & 7 & 1 & 8 & 48 & $<0.0005$ \\
\hline DRw8:DQ $\beta V$ & 6 & 0 & 17 & 38 & $<0.005$ \\
\hline DRw9:DQ $\beta$ VIIc & 3 & 0 & 4 & 54 & $<0.002$ \\
\hline
\end{tabular}

The figures shown represent the numbers of control subjects in each category of DR-DQ $\beta$ association. $p=$ significance level of the association

Tabie 7. Associations between DQ $\beta, D R \beta$ and DQ $\alpha$ RFLPs

\begin{tabular}{llll}
\hline Antigen & DR $\beta$ & DQ $\beta$ & DQ $\alpha$ \\
\hline DR2 & II & -VIa & $-6.2 \mathrm{~kb}$ \\
DR3 & III & -III & $-4.6 \mathrm{~kb}$ \\
& VI & -III & $-4.6 \mathrm{~kb}$ \\
DR4 & V & -IV & $-6.2 \mathrm{~kb}$ \\
& IV & - IV & $-5.5 \mathrm{~kb}$ \\
DR5 & IV & - V & $-5.5 \mathrm{~kb}$ \\
& V & -V & $-4.6 \mathrm{~kb}$ \\
DR7 & V & -VIa & $-6.2 \mathrm{~kb}$ \\
& VII & -VIIb & $-5.5 \mathrm{~kb}$ \\
DRw9 & VII & -VIIc & $-5.5 \mathrm{~kb}$ \\
\hline
\end{tabular}

The table shows the most commonly associated DR $\beta-D Q \beta-D Q \alpha$ RFLP combination(s) for selected DR antigens

with DRw9 and a subset of DR7. (2) DR3 was in linkage disequilibrium with DQBIII (as in Caucasoid subjects), but also showed an association with DQ $\beta I V$ not seen in Caucasoid subjects. (3) DQBVIa was strongly associated with DR2 (as in white Caucasoid subjects), but there was also a weaker (non-significant) association with DR5.

Of eight DR7-positive control subjects tested, six

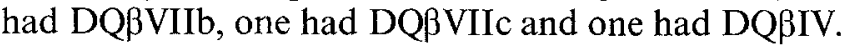
Among eleven DR7-positive diabetic patients, seven had DQBVIIc and five had DQBVIIb (one patient was heterozygous for the two RFLPs). DR7 was thus increased in frequency in patients only in combination with DQBVIIc (RR $=9.8(2.0-49) ; p<0.01) . \mathrm{DR} 7$ in combination with DQBVIIb was neutral $(\mathrm{RR}=1.4$ $(0.44-4.5) ; p=\mathrm{NS})$. DR7-DQ $\beta \mathrm{IV}$ was not seen in any patient. DRw9 was closely associated with DQBVIIc, in both patients and control subjects (RR for DRw9DQ $\beta$ VIIC $=5.5 \quad(1.6-19) ; \quad p<0.01) . \quad$ DR7-associated DQ $\alpha$ and DR $\beta$ RFLPs were as described for DR7 haplotypes in Caucasoid subjects [10, 24, 25] (see Table 7).

In control subjects, DR3 was associated with either DQ $\beta I I I$ or DQ $\beta I V$. DR $\beta$ and DQ $\alpha$ RFLPs also differed between these two subsets of DR3 (see Table 7). Eight of $19(42 \%)$ DR3-positive control subjects tested had

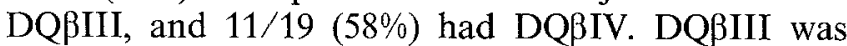


present in 14/15 (93\%) DR3-positive patients, whereas DR3-DQ $\beta I V$ was absent from the patient group (one DR3-positive patient had neither of these two DQ $\beta$ patterns). Thus, only the DR3-DQ $\beta$ III combination was increased in frequency in diabetic patients $(\mathrm{RR}=3.8$ $(1.5-9.8) ; p<0.01)$; for DR3-DQ $\beta \mathrm{IV}, \mathrm{RR}$ was 0.06 $(0.01-0.48)(p<0.01)$. The difference in proportions of the two DQ $\beta$ patterns between DR3-positive patients and DR3-positive control subjects was statistically significant $(p<0.001)$.

Eleven of $15(73 \%)$ DR4-positive patients had $D Q \beta I V$, but the remaining four had DQ $\beta$ V. The latter patients had the following DR antigens and DQ $\beta$ RFLPS - (1) DR3/4 (DQBIII/V); (2) DR3/4

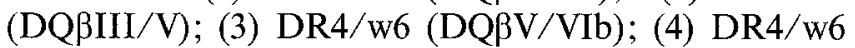
$(\mathrm{DQ} \beta \mathrm{V} / \mathrm{I})$. The single DR4-positive control subject tested had DQ $\beta I V$.

$\mathrm{DQ} \beta$ VIa was significantly associated with DR2, but was also found in 12/22 DR5-positive control subjects. In six of these subjects, the presence of DQBVIa could be accounted for by the second DR antigen (DR2 or DRw6), but in the remaining six subjects, this was not the case. DQ $\beta$ VIa was absent from the three DR5-positive patients.

\section{Discussion}

The Afro-Caribbean population of the United Kingdom is of recent origin, being principally derived from a wave of migration which occurred during the 1950s and 1960s. Our selection criteria excluded patients and control individuals with post-migration Caucasoid ancestry and our subjects are, therefore, genetically representative of the indigenous Negroid population of the Caribbean region. Current knowledge of HLA associations with Type 1 diabetes in Negroid subjects has relied heavily on studies from the United States, but the American Negroid population has a substantial proportion (approximately 20\%) of Caucasoid genetic admixture [27]. In the Negroid population of Jamaica, Caucasoid admixture has been estimated at 10\% [27], and thus, the subjects of the present study are genetically closer to the West African Negroid peoples from whom both American and Caribbean Negroid subjects are descended.

Our analysis indicated that four DR antigens are increased in frequency in Negroid patients with Type 1 diabetes - DR3, 4, 7 and w9. In all other races studied, DR7 is reduced in frequency in patients [28], and, thus, this antigen is a race-specific marker. Ethiopian $\mathrm{Ne}$ groid patients do not appear to show this association [23], possibly due to their distinct Negroid-Caucasoid ancestry. DRw9 shows only a weak predisposing effect in Caucasoid patients [12], but is increased in Japanese diabetic patients [11]. The DR4 association has been noted in previous studies of Negroid subjects [17-20, 23]. In Caucasoid subjects, the relative risk for DR3 is three to four [29], but our analysis indicated a value of approximately two for Negroid subjects. There was significant variation in relative risk estimates for DR3 in Negroid subjects, which may be due to Caucasoid genetic admixture in some of the populations studied. Both DR2 and DR5 were significantly reduced in frequency in Negroid patients with Type 1 diabetes. In Caucasoid subjects, the negative association of DR2 is well-recognised, but DR5 does not consistently confer a marked protective effect.

To investigate further these racial differences in DR antigen associations, we studied class II HLA RFLPs with DNA probes corresponding to the $D Q \alpha, D Q \beta$ and $\mathrm{DR} \beta$ chain genes.

DRw9, and a subset of DR7, were associated with a $\mathrm{DQ} \beta$ pattern (DQ $\beta \mathrm{VII})$ ) which has not been previously identified in other races $[10,24,25]$. This pattern was associated with $D Q \alpha$ and DR $\beta$ RFLPs which are also characteristic of Caucasoid DR7 and DRw9 haplotypes $[10,24,25]$. The frequency of DQ $\beta$ VIIc was markedly increased among Negroid diabetic patients compared with control subjects. As in Caucasoid subjects [10], DR7-DQBVIIb was not increased in Type 1 diabetes. These results suggest that the positive associations of DR7 and DRw9 with Type 1 diabetes in Negroid subjects correlate with variation in the DQ subregion on DR7 and DRw9 haplotypes in this race. DNA sequencing of the class II genes on the diabetes-associated DR7 haplotype is now required to confirm the results of RFLP analysis.

The other DQ $\beta$ patterns seen in Negroid subjects are also found in Caucasoid subjects $[10,24,25]$. Their linkage disequilibrium relationships with DR antigens were also similar to those seen in the latter groups, with certain important exceptions. In Caucasoids, one DQ RFLP pattern, DQ $\beta I I I-D Q \alpha 4.6 \mathrm{~kb}$, is found in the great majority of DR3-positive subjects (patients and controls). This pattern corresponds to the DR3-DQw2 haplotype. In Negroids, DR3 in control subjects was associated with two patterns - DQ $\beta I I I-D Q \alpha 4.6 \mathrm{~kb}$, and DQßIV-DQ $\alpha 6.2 \mathrm{~kb}$. This split has recently been recognised by others [30]. The latter pattern corresponds to the DR3-DQ"blank" haplotype, present in approximately $50 \%$ of DR3-positive American Negroid subjects [30]. DNA sequence analysis has shown that the DR3-DQ"blank" and DR3-DQw2 DQ $\alpha$ chains are very similar, but the DR3-DQ"blank" DQ $\beta$ chain is similar to that previously described for a DR4-DQ"blank" haplotype [30].

In the present study, only the DR3-DQw2 pattern was increased in frequency in Negroid patients, whereas the DR3-DQ"blank" pattern was absent from this group. The negative association of DR3-DQ"blank" with Type 1 diabetes explains the lower relative risk for DR3 in Negroid subjects compared with Caucasoid subjects, and is consistent with the view that the DR3related component of genetic susceptibility to Type 1 diabetes is DQ-related. No firm conclusion can be 
reached regarding the relative roles of $D R$ and $D Q$ in DR3-related susceptibility, however, because DR3DQw2 and DR3-DQ"blank" have distinct DR $\beta$ RFLPs, implying that their DR $\beta$ chains are also different.

DQBVIa is associated with DR2 in Caucasoid subjects and with DRw6 in North Indian subjects but has a protective effect against Type 1 diabetes in both groups [10]. In Negroid subjects, DQBVIa was strongly associated with DR2, but there was also evidence for an association with DR5. Although the latter association was not statistically significant, it is known that DR5 haplotypes frequently carry DQw1 (of which DQBVIa is a subset) in Negroid subjects [31]. As in white Caucasoid and North Indian subjects, DQBVIa in Negroid subjects was markedly reduced in frequency in patients with Type 1 diabetes. Thus, a single DQ $\beta$ pattern with varying $D R$ antigen associations in different races confers a consistent protective effect against Type 1 diabetes, supporting the view that a component of susceptibility to the condition is DQ-encoded.

Two DQ-defined subsets of DR4 - DQw3.1 and DQw3.2 - have been described using serology and RFLP analysis; DQw3.1 correlates with a positive reaction with TA10 antisera, whereas DQw3.2 is TA10negative [32]. In our terminology, $D Q \beta I V$ is characteristic of DQw3.2, and DQ $3 V$ corresponds to DQw3.1. Current evidence indicates that DQw3.2 is present in approximately $90 \%$ of DR4-positive Caucasoid diabetic patients, whereas DQw3.1 is reduced in frequency in patients [9]. This has been interpreted as evidence that DR4 susceptibility is DQ-encoded. If, however, the negative association of DR4-DQw3.1 with Type 1 diabetes is a general phenomenon, then the low frequency of DR4 in the Afro-Caribbean Negroid control population should lead to a very low frequency of DR4-DQ $\beta V$ in patients of this race. In the present study, however, four of fifteen DR4-positive patients had DQ $\beta V$ rather than DQBIV. DQ may not, therefore, be the only locus influencing susceptibility to Type 1 diabetes on DR4 haplotypes. This view is supported by a recent study of DR4-DQw3 subtypes (defined by TA10 serology) in Caucasoid patients, which found that the specific positive association of DR4-DQw3.2 with Type 1 diabetes may only apply to DR3/4 heterozygous subjects; among DR4-positive, DR3-negative patients the frequencies of DQw3.1 and 3.2 were similar to those found in DR4-positive control subjects [33].

In conclusion, trans-racial genetic analysis indicates that the DQ region has a primary role in determining predisposition to Type 1 diabetes. This is supported by two lines of evidence from this study. First, the increased frequencies of DR7 and DRw9 in Type 1 diabetes in Negroid subjects correlated with the association of these antigens with a novel DQ $\beta$ RFLP which was markedly increased in frequency among patients. Second, a DQ $\beta$ RFLP in linkage disequilibrium with different DR antigens in three races, confers a consistent protective effect against Type 1 diabetes. Furthermore, our results are compatible with a model in which the DR3 association is mediated by HLA-DQ. Studies in Caucasoid subjects support a role for DQ in DR4-related susceptibility also, but the possibility of an additional nonDQ component of DR4 predisposition cannot be excluded.

Acknowledgements. We thank our Research Sister, B. Rowe, for help in sample collection, and the following physicians for allowing access to their patients - J.K. Cruickshank, R.D.G. Leslie, P.Drury, S. Walford, K.Taylor, P.Rayner, M.Honeyman, T.Harvey, S. Tomlinson. The cDNA clones were kindly provided by Prof. P.A.Peterson, University of Uppsala, Sweden. This study was supported by an MRC Project Grant. We are also grateful to Nordisk UK and Ames UK for financial support. JF is an MRC Training Fellow. CM is a Wellcome Trust Research Fellow. OO is a Novo Research Fellow. DJ is an Eli Lilly Research Fellow. The data presented in this paper were included in a thesis submitted by JF to the University of London for the MD degree.

\section{References}

1. Owerbach D, Lernmark A, Platz P, Ryder LP, Rask L, Peterson PA, Ludvigsson J (1983) HLA-D region beta-chain DNA endonuclease fragments differ between HLA-DR identical healthy and insulin-dependent diabetic individuals. Nature 303:815-817

2. Cohen-Haguenauer $\mathrm{O}$, Robbins $\mathrm{E}$, Massart $\mathrm{C}$, Busson $\mathrm{M}$, Deschamps I, Hors J, Lalouel J-M, Dausset J, Cohen D (1985) A systematic study of class II- $\beta$ DNA restriction fragments in insulindependent diabetes mellitus. Proc Natl Acad Sci USA 82: 3335-3339

3. Bohme J, Carlsson B, Wallin J, Moller E, Persson B, Peterson PA, Rask L (1986) Only one DQ- $\beta$ restriction fragment pattern of each DR specificity is associated with insulin-dependent diabetes. J Immunol 137: 941-947

4. Nepom BS, Palmer J, Kim SJ, Hansen JA, Holbeck SL, Nepom GT (1986) Specific genomic markers for the HLA-DQ subregion discriminate between $\mathrm{DR}^{+}$insulin-dependent diabetes mellitus and DR4 ${ }^{+}$seropositive juvenile rheumatoid arthritis. J Exp Med 164: 345-350

5. Schreuder GMTh, Tilanus MGJ, Bontrop RE, Bruining GJ, Giphart MJ, van Rood JJ, de Vries RRP (1986) HLA-DQ polymorphism associated with resistance to type 1 diabetes detected with monoclonal antibodies, isoelectric point differences, and restriction fragment length polymorphism. J Exp Med 164: 938-943

6. Tait BD, Boyle AJ (1986) DR4 and susceptibility to type 1 diabetes mellitus: discrimination of high and low risk DR4 haplotypes on the basis of TA10 typing. Tissue Antigens 28: 65-71

7. Bruserud O, Paulsen G, Markussen G, Lundin K, Thoresen AB, Thorsby E (1987) Genomic HLA-DQB polymorphism associated with insulin-dependent diabetes mellitus. Scand J Immunol 25: 235-243

8. Henson V, MacLaren N, Riley W, Wakeland EK (1987) Polymorphism of $\mathrm{DQ}_{\beta}$ genes in HLA-DR4 haplotypes from healthy and diabetic individuals. Immunogenetics 25: 152-160

9. Todd JA, Bell JI, McDevitt HO (1987) HLA-DQ $\beta$ gene contributes to susceptibility and resistance to insulin-dependent diabetes mellitus. Nature 329: 599-604

10. Fletcher $\mathrm{J}$, Odugbesan O, Mijovic C, Mackay E, Bradwell AR, Barnett AH (1988) Class II HLA DNA polymorphisms in Type 1 (insulin-dependent) diabetic patients of North Indian origin. Diabetologia 31: $343-350$

11. Bertrams J, Baur MP (1984) Insulin-dependent diabetes mellitus. In: Albert ED, Baur MP, Mayr WR (eds) Histocompatibility testing 1984. Springer, Berlin Heidelberg New York, pp 348-358

12. Svejgaard A, Jakobsen BK, Platz P, Ryder LP, Nerup J, Christy M, Borch-Johnsen K, Parving H-H, Deckert T, Molsted- 
Pedersen L, Kuhl C, Buschard K, Green A (1986) HLA associations in insulin-dependent diabetes: search for heterogeneity in different groups of patients from a homogeneous population. Tissue Antigens 28: 237-244

13. Southern EM (1975) Detection of specific sequences among DNA fragments separated by gel electrophoresis. J Mol Biol 98: 503-517

14. Thomson $G$ (1981) A review of theoretical aspects of HLA and disease associations. Theor Popul Biol 20: 168-208

15. Mathews JD (1984) Statistical aspects of immunogenetic associations with disease. In: Simons MJ, Tait BD (eds) Detection of immune-associated genetic markers of human disease. Churchill Livingstone, London, pp 106-136

16. Tiwari JL, Terasaki PI (1985) The data and statistical analysis. In: Tiwari JI, Terasaki PI (eds) HLA and disease associations. Springer, Berlin Heidelberg New York, pp 185-210

17. Rodey GE, White N, Frazer TE, Duquesnoy RJ, Santiago JV (1979) HLA-DR specificities among black Americans with juvenile-onset diabetes. N Engl J Med 301: 810-812

18. Zeidler A, Loon J, Frasier SD, Kumar D, Penny R, Terasaki P (1980) HLA-DRw antigens in Mexican-American and blackAmerican diabetic patients. Diabetes 29:247-250

19. Reitnauer PJ, Roseman JM, Barger BO, Murphy CC, Kirk KA, Acton RT (1981) HLA associations with insulin-dependent diabetes mellitus in a sample of the American black population. Tissue Antigens 17: 286-293

20. Omar MAK, Hammond MG, Asmal AC (1984) HLA-A, B, C and DR antigens in young South African blacks with Type 1 (insulindependent) diabetes mellitus. Diabetologia 26: 20-23

21. Orren A, Taljaard D, Du Toit E (1985) HLA-A, B, C and DR antigen associations in insulin dependent diabetes mellitus (IDDM) in South African negro (black) and Cape coloured people. Tissue Antigens 26:332-339

22. MacDonald MJ, Famuyiwa OO, Nwabuebo IA, Bella AF, Junaid TA, Marrari M, Duquesnoy RJ (1986) HLA-DR associations in black type I diabetics in Nigeria: further support for models of inheritance. Diabetes 35: 583-589

23. Ottenhoff THM, Mengistu M, Tadesse G, De Vries RRP, Converse PJ (1987) HLA-DR and DQ antigens in insulin-dependent diabetics in Ethiopia. Tissue Antigens 30: 193-197

24. Carlsson B, Wallin J, Bohme J, Moller E (1987) HLA-DR-DQ haplotypes defined by restriction fragment analysis: correlation to serology. Hum Immunol 20: 95-113
25. Bidwell JL, Bidwell EA, Savage DA, Middleton D, Klouda PT, Bradley BA (1988) A DNA-RFLP typing system that positively identifies serologically well-defined and ill-defined HLA-DR and DQ alleles, including DRw10. Transplantation 45: 640-646

26. Spielman R, Lee JS, Bodmer WF, Bodmer J, Trowsdale J (1984) Six HLA- $D_{\alpha}$ chain genes on human chromosome 6: polymorphisms and associations of $\mathrm{DC}_{\alpha}$-related sequences with $\mathrm{DR}$ types. Proc Natl Acad Sci USA 81: 3461-3465

27. McEvedy C, Jones R (1978) The Americas. In: McEvedy C, Jones R (eds) Atlas of World Population History. Penguin, UK

28. Svejgaard A, Platz P, Ryder LP (1980) Insulin-dependent diabetes mellitus. In: Terasaki PI (ed) Histocompatibility Testing. UCLA Tissue Typing Laboratory, Los Angeles, pp 638-656

29. Tiwari JL, Terasaki PI (1985) Juvenile diabetes mellitus (insulindependent). In: Tiwari JI, Terasaki PI (eds) HLA and disease associations. Springer, Berlin Heidelberg New York, pp 185-210

30. Hurley CK, Gregersen P, Steiner N, Bell J, Hartzman R, Nepom G, Silver J, Johnson AH (1988) Polymorphism of the HLA-D region in American blacks. J Immunol 140:885-892

31. Oudshoom M, Schreuder GMT, Campbell EM, duToit ED (1984) Segregation of DQ and DR: "exceptions to the rule". In: Albert ED, Baur MP, Mayr WR (eds) Histocompatibility Testing 1984. Springer, Berlin Heidelberg New York, pp 419-420

32. Kim SJ, Holbeck SL, Nisperos B, Hansen JA, Maeda H, Nepom GT (1985) Identification of a polymorphic variant associated with HLA-DQw3 and characterized by specific restriction sites within the DQ $\beta$-chain gene. Proc Natl Acad Sci USA: $8139-8143$

33. Tait BD, Mraz G, Harrison LC (1988) Association of HLA-DQw3 (TA10 ${ }^{-}$) with type 1 diabetes occurs with DR3/4 but not DR1/4 patients. Diabetes 37: 926-929

Received: 26 July 1988

and in revised form: 18 October 1988

Dr. J. Fletcher

Department of Medicine

Queen Elizabeth Hospital

Edgbaston

Birmingham B15 2TH

UK 